\title{
A Review of Leadership Styles: Maimonides and Spinoza
}

\author{
Liron Hoch \\ Department of Interdisciplinary Studies, Zefat Academic College, Zefat, Israel \\ Email: lironhoch@hotmail.com
}

How to cite this paper: Hoch, L. (2022). A Review of Leadership Styles: Maimonides and Spinoza. Open Journal of Leadership, 11, 19-33.

https://doi.org/10.4236/ojl.2022.111003

Received: January 9, 2022

Accepted: March 5, 2022

Published: March 8, 2022

Copyright $\odot 2022$ by author(s) and Scientific Research Publishing Inc. This work is licensed under the Creative Commons Attribution International License (CC BY 4.0).

http://creativecommons.org/licenses/by/4.0/

\begin{abstract}
This paper compares and contrasts the leadership styles learned from the worldviews of Maimonides's and Spinoza's thinking. The paper seeks to unearth the similarities and differences between these two models for the purpose of proposing suitable leadership styles for different environmental conditions and desired relationships between leaders and followers, thus, ensuring a connection between the leadership style and the nature of its audience. The paper claims that Maimonides's concept is similar to that of the flexible leadership style, while Spinoza's concept is similar to an affective leadership style. The similarities between these models are that they can operate in a complex, challenging environment through the use of ideal communication, persuasion, awareness, and activism. Both models believe in the political structure as necessary for human life and also where one needs a political framework to fulfil his/her destiny. Further, these models acknowledge that an individual is part of society and is shaped by it. Therefore, the individual is compelled to give of him/herself to society. However, the paper outlines several differences between these two models of leadership styles. The basis of these divergent views lies in the conception of God and how the two worldviews view the functions of prophets and prophecy. The differences also emanate from how each worldview views issues to do with society and human ideals. For example, Maimonides's flexible leadership is characterized by a hierarchical mode of leadership headed by a single leader, and it demands obedience and does not put emphasis on the enjoyment of things. These characteristics are reflected by the way God rules the earth as the exclusive sovereign from the top and embody the hierarchical order which requires obedience to the commandments of religion, including obedience in beliefs and opinions. On the contrary, Spinoza's affective leadership is characterized by non-hierarchical leadership, obedience is not a requirement, and emphasis is placed on the enjoyment by both leaders and followers. There is also no difference between God and nature; in fact, the fundamental conceptions of
\end{abstract}


monotheistic religions are criticized. The paper further outlines the benefits and limitations of each leadership model and concludes by recommending that the research may provide a basis by which to match an audience, with its unique conceptual or operational structure, to the appropriate leadership style.

\section{Keywords}

Leadership, Hierarchy, Obedience, Enjoyment, MFL, SAL Maimonides, Spinoza, Prophet, Prophecy, Society

\section{Introduction}

This article examines two fundamentally different styles of leadership: Maimonides's flexible leadership (henceforth MFL), and Spinoza's affective leadership (henceforth SAL).

According to this article, MFL, the concept of flexible leadership reflected by Maimonides, refers to adapting one's method of leadership to complex situations as well as diverse and changing contexts. A flexible leader is able to influence a wide range of people (Hoch \& Bentolila, 2021; Kaiser \& Overfield, 2010; Jia et al., 2018).

The article The Ethics of Affective Leadership: Organizing Good Encounters without Leaders (Munro \& Thanem, 2018) uses Spinoza's ethics to formulate an idea of affective leadership (SAL). According to the article, SAL includes the following principles: a basic suspicion of any obedience to individual leaders; involvement of free members capable of collective action; cultivation of joyful affects or emotions which increase collective powers of action and avoidance of sad emotions; participation in joyful encounters consistent with our reason; and organization of positive encounters through the cultivation of friendships. Maimonides provides an exemplary representation of flexible leadership. However, there are three aspects for which he cannot be included under the heading of affective leadership according to the principles presented by Munro \& Thanem (2018): skepticism towards obedience, opposition to the idea of hierarchical leadership, and a strong need for enjoyable encounters. Indeed, these three elements are inconsistent with Maimonides's mode of leadership.

In general, while MFL puts in great effort to serve its followers with wisdom and sensitivity, SAL takes another step, expressed in the three elements mentioned, to close the distance between leaders and followers. The difference between the physical and metaphysical worldview of Maimonides and that of Spinoza reflects the leadership style of each. Maimonides has a hierarchical worldview in which God governs reality and, accordingly, a leader governs society. By contrast, Spinoza has a non-hierarchical worldview that is often described as the pantheistic worldview (Mander, 2012; Melamed, 2018; Popejoy, 2019; Gilead, 2021). The concept of proper leadership that stems from that worldview is shared leadership. 
In exploring the differences between MFL and the SAL of Spinoza's affective ethics, we can identify the root difference between flexible leadership and affective leadership and speculate which leadership style is appropriate for which situation or audience. It should be emphasized that MFL and SAL are models; even if an organization does not realize all the values of one of the models, proximity and distance can still be identified from each of the models.

Although this article is theoretical in its aspect and is a demonstration of the connection between the paradigmatic conception of reality and the conception of leadership, there is also potential for its application. Organizations with specific goals can adopt a leadership style and thus relate, directly and indirectly, to a different paradigm.

\section{Background, Purpose, and the Structure of the Study}

A few words about the two thinkers: the Jewish leader Maimonides (1138-1204) was a prominent philosopher, among the greatest of the poskim (halakhic decisors), a skilled physician, and an influential scientist (Halbertal, 2013; Shemesh, 2018). Benedict Spinoza (1632-1677) was a Dutch-Jewish philosopher from a converso family that had returned to Judaism. Spinoza is considered a pioneer of biblical criticism and one of the founders of secularism, skepticism, and modernity in general (Yovel, 1989).

This research is based on the writings of Maimonides and Spinoza, as well as scholarship on the two thinkers and existing literature on leadership. Two articles from the primary basis for this study: Maimonides. Flexible Leadership (Hoch \& Bentolila, 2021) and The Ethics of Affective Leadership: Organizing Good Encounters without Leaders (Munro \& Thanem, 2018). The first article discusses the leadership style of Maimonides, while the second article addresses the leadership style learned from Spinoza's thought. Through a study of these two models, we will characterize each model and unearth the similarities and differences between them. In this way, it will be possible to propose the use of one or both of these leadership styles for diverse organizations. Familiarity with the models, including their advantages and limitations, can help to adapt a leadership model to a project style, examining the suitability of the desired relationship between leaders and followers and ensuring a connection between the leadership style and the nature of its audience.

The main contribution of the comparison between the two models is that, on the one hand, one can see how a paradigmatic perception of reality affects leadership style, and on the other hand, one can adopt a leadership style according to recognition of organizational goals and its own character. The results of this study may enable us to tailor a desired leadership style to specific audiences.

The comparison between MFL and SAL will be through an analysis of the differences between Maimonides and Spinoza that emerge from their writings and the research literature. In general, the topics to be discussed are the perceptions of the hierarchy underlying reality: the attitudes to obedience and enjoyment in doing, the place of the principles of faith, leadership in a good society, prophet, 
prophecy, and human perfection.

\section{Literature Review}

Flexible leadership is a method or approach that is appropriate for diverse and changing contexts and can be manifested in different ways (Kaiser \& Overfield, 2010; Yukl \& Mahsud, 2010). The flexible leadership style is characterized by a wide repertoire of behaviors that can be adapted to a variety of situations. This style contains the ability to know when to use each behavior, as well as the specific skills to perform the required actions in order to solve new challenges in a complex reality. Flexible leadership rests on ideas from several disciplines: leadership, human resources management, strategic management, organizational theory, and organizational change (Yukl, 2008; Jones \& Nieto, 2015). A flexible leader has the ability to balance competing values, taking into account all the variables in a complex situation (Landin, 2017).

Flexible leadership contains a dynamic and multidimensional structure of skills; different skills are activated depending on the context (Wilkes et al., 2011). It requires a high level of emotional intelligence, intuition, interpersonal ability, logic, and the capacity to adopt the correct course of action after assessing a situation (Novicevic et al., 2011; Baron et al., 2018; Hurtado \& Mukherji, 2015; Heemsbergen, 2006; Pillay, 2010).

Cognitive flexibility entails emotional capabilities based on self-awareness, awareness of others, task awareness, and situation awareness (Hurtado \& Mukherji, 2015). A leader endowed with these skills is able to persuade a wide variety of people to trust and follow him. In addition, a leader of this type considers the nature of his audience (Jia et al., 2018).

Maimonides wrote a monumental book that encompassed the entirety of Jewish law with the aim of being open and accessible to all. In addition, Maimonides created a connection between philosophical-scientific ideas and the religious world (Halbertal, 2013: Introduction). The Epistles of Maimonides document Maimonides's unique leadership, as well as his guidance in dealing with a variety of spiritual crises (Halkin \& Hartman, 1993). In Jewish thought, Maimonides is considered an exemplary leader who acted according to reason and common sense (Idel, 2008; Shapira, 2018).

On the basis of Spinoza's affective ethics, Munro \& Thanem (2018) conceptualize affective leadership as follows:

Affective leadership is characterized by a basic suspicion of any obedience to individual leaders. All obedience other than obedience to reason is considered slavish and unethical. This style of leadership also features "people as free members of the multitude, who are...capable of collective action without interference from 'ethical leaders', cultivation of joyful affects which increase collective powers of action, and avoidance of sad emotions which reduce them. In affective leadership, leaders participate actively in joyful encounters that are nonetheless compatible with our reason (Lloyd, 2018)". Thus, affective leaders are able to avoid the 
problem of ignorance, as well as the passive influence of external causes.

Munro and Thanem continue: "affective leadership emerges in joyful encounters that accord with our reason. Rather than being ignorant and passively affected by external causes, we enhance our capacity to affect and be affected as we experience and understand the limits of our freedom as well as the causes of joyful affects."

This leadership style also enables the organization of positive encounters through the cultivation of friendships, which helps participants to work toward their mutual welfare. It encourages and develops democratic relationships, allowing people to think independently and express their thoughts without fear. The care and empowerment fostered by these positive interactions allow people to rise above the sad outcomes, pain, and suffering generated by the ideals of capitalist institutions (Munro \& Thanem, 2018).

Spinoza defines compassion and kindness as joyful and virtuous affects that enhance our power to influence and be influenced by others. The ability of participants to use collective power is necessary for the cultivation of any virtuous affect, as well as for the good life. Spinoza teaches us that our ability to improve virtuous affects as part of a collective effort is preferable to the ostensible virtues that exist in individual leaders (Munro \& Thanem, 2020).

Six types of leadership form the background for deepening the two leadership styles that this article examines: Commanding, Visionary, Affiliative, Democratic, Pacesetting, and Coaching (Vasilescu, 2019). The article also corresponds with an idea as a service provider (Gandolfi \& Stone, 2018).

Our aim is to clarify the connection between the paradigmatic conception of reality and the conception of leadership and its application, a connection which is missing in the existing research literature.

\section{The Similarities and Differences between MFL and SAL}

MFL has been extensively discussed in another article (Hoch \& Bentolila, 2021). The article maintained that Maimonides's character and activity as a leader is expressed in a wide range of behaviors adapted to a complex and diverse reality, stemming from an overall capacity for self-awareness, awareness of the other, awareness of the task, and awareness of the situation.

It is not inconceivable that SAL would contain capabilities similar to those of MFL, such as a broad repertoire of measured, thoughtful behavior or the ability to make decisions amidst competing values. Also, both styles are equipped to face new challenges in a complex reality by means of communication, persuasion, awareness, and activism.

Despite the apparent similarity between these two styles, SAL is not satisfied with the benefits offered by MFL, so long as it continues to feature: 1) A hierarchical mode of leadership, headed by a single leader; 2) A demand for obedience; 3) A lack of emphasis on the enjoyment of doing. Unlike MFL, SAL is characterized by non-hierarchical leadership, does not require obedience, and enables em- 
powering and shared work enjoyed by both leaders and followers.

To this it should be added that SAL includes joint leadership, a wide range of legitimate opinions, and the nonhierarchical accommodation of desires. In SAL, the potential for skill diversification increases, as does the quality of the various capabilities; thus, it is a particularly efficient mode of leadership. SAL's rich repertoire, as well as the many advantages of this leadership style, is related to the fact that it involves multiple leaders acting with pleasure out of a shared responsibility for both personal and general good. Together, this comprises a single broad dimension of leaders who themselves are also led (Munro \& Thanem, 2018; Munro \& Thanem, 2020).

Our proposal is to examine the nature and purpose of organizations in light of the two models of leadership and accordingly to examine the suitability of each of the two models as the most appropriate paradigm for a specific organization. Below we will present the root of the paradigmatic difference between MFL and SAL.

\section{The Difference in Metaphysical Conception as a Basis for the Differences in the Conception of Leadership}

Maimonides's worldview (Davies, 2011) is hierarchical, with God at the top. This paradigm does not remain only in the physical and metaphysical realm, but rather exists in a variety of social structures, which themselves embody the hierarchical order. Unlike Maimonides, Spinoza understands God and nature (Eisenberg, 2019) as a single entity (Deus sive Natura). Spinoza opposed a hierarchical concept of reality in which God was presented as standing at the head of the world, and his creatures as obligated to fulfill his commandments out of absolute obedience. One of the sociological consequences of a non-hierarchical conception of reality that can be learned from Spinoza's thought is that the whole of reality functions in harmony, even without a leader to operate or arrange it (Newlands, 2010). This is as true in physical and metaphysical reality as it is in social reality.

A hierarchical worldview gives rise to a hierarchical conception of leadership, on the assumption that a hierarchical structure exists everywhere. By contrast, a non-hierarchical worldview, in which each factor is significant, produces shared and broader leadership. SAL is close to a worldview, often attributed to Spinoza, known as pantheism, which identifies God with nature and views God as present in all things (Mander, 2012; Melamed, 2018; Popejoy, 2019; Gilead, 2021). Thus, Spinoza's worldview is reflected in his sociopolitical conceptions (Gatens et al., 2021).

It seems that Spinoza's philosophy contains conflicting values. On the one hand, it emphasizes the value of personal freedom (Klein, 2019; Youpa, 2019; NaamanZauderer, 2019). One of the strongest expressions of this value is that in a free society, every individual is allowed to think his thoughts and express them without fear. On the other hand, Spinoza sees value in social partnership, that is, in the collective; for instance, he maintains that the individual is bound by the laws of 
society.

This apparent dichotomy-between a perception that centers the individual and one that centers the collective-can be reconciled through Spinoza's belief that the individual is part of the collective and can help empower it, while the collective in turn can help empower the individual (Tucker, 2019). According to this view, when one side is strengthened, then the other is also strengthened; thus, the collective and the individual are strengthened together.

The main element that distinguishes MFL from SAL is that SAL strongly opposes obedience, while Maimonides requires obedience to Jewish law (halakha). Indeed, Maimonides can even be understood as the thinker who introduced doctrinal orthodoxy into Judaism. Maimonides established principles for Judaism in which every Jew is ostensibly obligated to believe. That is to say, beyond the fact that Maimonides requires obedience to the commandments of religion (halakha), he also requires obedience in the field of beliefs and opinions (Kreisel, 2012: Chapter 6). In this way, obedience is a fundamental element of Maimonides's thought, such that he cannot be considered to share the principles of SAL. The second point of distinction is that Maimonides maintains a hierarchical understanding of reality in which God is the exclusive sovereign; thus, in MFL, the human-social reality is also constructed in accordance with this structure, unlike the non-hierarchical leadership propounded by SAL. The third is the ideal of pleasure in action. In SAL, pleasure exists as a fundamental principle, whereas for Maimonides, pleasure is a secondary matter compared to absolute obedience to the laws of religion as determined by the absolute, that is, God.

According to Spinoza, a person who lives among people whose nature is similar to his own will carry out his actions effectively and powerfully (Spinoza, 2003). It seems that when people possess a similar nature and act according to reason, there is no need for hierarchy and obedience that create alienation, since the deeds are done out of joy (LeBuffe, 2018; Naaman-Zauderer, 2019). Spinoza is not a utopian, but he is optimistic about the possibility of creating a just society for the individual and the collective.

From here we move on to the question of the function of faith in the thought of Maimonides and Spinoza.

\section{The Importance of Obedience and the Place of the Principles of Faith}

Maimonides is motivated by the desire to save people from misconceptions (Carrasquillo, 2019). In his opinion, a philosophical mistake is a failure of faith. According to Maimonides, a Jew is obligated to believe in all thirteen principles of faith. As such, in matters of religious thought, Maimonides is dogmatic and not pluralistic (Lemler, 2018). Obedience to the dogmatics of thought is more important to Maimonides than obedience to practical commandments. It is difficult, almost impossible, to wait for voluntary obedience of thought, and so a degree of coercion is necessary in order to conform to the dogmatics of thought. The belief in thirteenprinciples does not derive from the person himself, but is 
forced by an external authority. Hence, in Maimonides's system, openness and pleasure-which stem from the individual's unforced desires-are no longer valued.

MFL is reflected in the accessibility of philosophical knowledge and its adaptation to the simple believer, thus bringing him closer to the truth. For his part, Spinoza presents seven principles of faith, in his opinion founded on a single main principle: Love your neighbor as yourself. According to Spinoza, the purpose of the faith expressed in biblical narratives is not philosophical truth, but social practice (Grossman, 2020; Arbib, 2021). In his opinion, faith requires godliness, a practice whose purpose is the observance of the laws that aid the social order. Is this conception of faith beneficial to a social life of peace and brotherhood? Spinoza leaves this as an open question. Although man is obligated in practical laws, the great space that Spinoza develops is the space of thought. In his view, no one has the right to interfere in questions of metaphysical truths or oblige individuals and society to believe in certain truths. In these matters, every man deserves to have complete freedom (Youpa, 2019; Naaman-Zauderer, 2019).

In such a society, even if there appears to be obedience, it is a matter of limited obedience of actions and not obedience of thoughts. In SAL, a person is allowed to think his own thoughts and exchange thoughts with others without fear. This resistance to obedience of thought allows for a transfer of ideas motivated by the desire to provide and receive additional opinions, not by a so-called hierarchical assumption of more- or less-true opinions.

\section{The Place of Leadership in a Good Society}

Like Aristotle, Maimonides maintains that man is a political animal (Weiler, 2018). Unlike other animals in the wild, the difference between individual humans is enormous; therefore, a leader must balance and regulate the actions of the people, giving them uniform norms and common customs so that the basic difference between them disappears and they may act in a coordinated fashion (Maimonides, 1910).

According to Spinoza (Spinoza, 2013), people cannot establish their lives or cultivate their spirits without mutual help; this gives rise to the need for a governing body. The right of the government or the authorities is a natural right, defined by the capacity of the authorities (Přibáň, 2018).

Although Maimonides and Spinoza alike see the political structure as necessary for human life, Maimonides places politics in the service of theology and the fulfillment of theological ideas; in contrast, according to Spinoza, the political sphere is forbidden to impose beliefs and opinions on private subjects. These disparate understandings of the proper connection between politics and theology reflect the personal differences between Maimonides and Spinoza. Maimonides was the head of the religious Jewish establishment, and his ambition was to influence his audiences in matters of belief and opinion. Spinoza, who lived outside his community and experienced personal exclusion, wanted to keep politics away from mat- 
ters of belief and opinion (Yovel, 1989; Naaman-Zauderer, 2019). In addition to the question of social order, the two thinkers also diverge with regard to the question of the perfect person and his connection to the perfect society (Klein, 2019).

Maimonides claims that the Torah has two main goals (Dascalu, 2017): social perfection and individual perfection (Maimonides, 1910). A leader is necessary for the attainment of these goals. Social perfection is necessary in order to reach individual perfection, and the way to maintain social wholeness is with the help of a leader.

The final topic discussed by Maimonides's monumental Mishneh Torah is the laws of kings and wars. The first commandment in this section is the appointment of a king. The importance of the leader's function is further expressed in his Guide for the Perplexed, where he stipulates that the great diversity among human beings requires a flexible leader who will coordinate authoritatively between his people in order to create a society of justice and morality (Maimonides, 1910). As such, Maimonides argues that both social perfection and the perfection of individuals in society require a hierarchy headed by a flexible leader.

Like Maimonides, Spinoza also connected social perfection with individual perfection. According to Spinoza, a person who acts according to reason and lives according to the common decision of his society lives a much freer life than one who lives in solitude and obeys only for himself (Spinoza, 2003). Spinoza explains that the rational person strives to fulfill the laws of society, which are the rules of life and the common good, in order to live more freely.

The happiness of the individual comes precisely from the decision of the whole society, which is applied to the individual, and not from a law created by the individual for himself. That is, a collective decision serves the individual well and empowers him. The social ideal is one of great partnership and mutual fertilization, and not the isolation of the individual from society, or on the other hand, the absorption of the individual in society.

In Spinoza's view, there are significant benefits to the creation of a common human society through shared customs and dedication to the broad cultivation of the ideal of peace and friendship (Přibán̆, 2018). In order to be freer and happier, the wise man understands that fulfilling the common laws of the state is self-interest greater than self-obedience. A good human society has the ability to empower the individual far more than he can empower himself alone.

According to both Maimonides and Spinoza, one needs a political framework to fulfill his individual destiny. The difference between the two thinkers is in the activity of the individual within the general framework. The individual in Maimonides's society is more passive than a person with self-discipline and active initiative in Spinoza's society.

This indicates a fundamental difference between MFL and SAL. While MFL emphasizes the leader, characterized by a capacity for diverse and flexible activity, SAL encourages collaborative activity between a wide range of styles, collaborating without hierarchy and driven by pleasure (Přibáň, 2018).

According to Maimonides and Spinoza, good individuals build a good society, 
and good society is a condition for the development of the individual (Whitman, 2020). The question then arises: is there a difference between them with regard to the priority between the individual and the collective?

If we accept the assumption that the end of a book expresses a principal idea, an important distinction can be made between Maimonides and Spinoza. Maimonides finished his Guide for the Perplexed (Maimonides, 1910) with the idea that the perfect person, who has achieved the supreme wisdom, must be committed to leading the public (Kreisel, 2018). Spinoza, who knew the Guide for the Perplexed, concludes his Ethics with words of praise to a man of intellectual perfection who is aware: of himself, of the necessary occurrence of reality, and of God (p. 402). This person lives in complete satisfaction.

Thus, while Maimonides concludes his book with a social mission, Spinoza concludes his book with personal redemption as a result of the supreme intellectual attainment. MFL sees the leader as a functionary for the service of the collective, while SAL ultimately sees the collective as a mechanism for the service of individuals (Dahlbeck, 2021).

Both Maimonides and Spinoza respond to the Bible, but, as we shall see below, they reach different conclusions regarding prophecy and human perfection, as well as the leadership function of the prophet.

\section{Prophet, Leader, and Human Perfection}

In the first part of Guide for the Perplexed, Maimonides argues that the leader of a state should be a prophet. All his actions should be performed wisely, with common sense, and in a balanced way, and not out of caprice, anger, resentment, hatred, or any other negative personality trait (see also (Maimonides, 1983); (Maimonides, 1912); (Hancock, 2021)). The goal of all the leader's deeds and actions should be to achieve the greatest benefit for the most people. The supreme human goal, expressed in the prophet, is the perfection of intellectual attainment; however, Maimonides aims at the stage of doing that comes after attainment by way of grace, charity, and justice (Maimonides, 1910). Maimonides concludes the chapter, and in fact the entire book, with the idea that the supreme human purpose is to make one's deeds resemble the acts of God. That is, the leader will govern society similarly to the way God governs the world (Weiler, 2018; Whitman, 2020; Whitman, 2020).

It should be emphasized that Maimonides strongly opposes any anthropomorphic depiction of God (Mahmoodi, 2018). He devotes many chapters to negative theology - that is, the negation of all descriptions of God (Fagenblat, 2020). And yet the prototype that Maimonides recommends for the greatest human deeds is God, who supposedly leads the world with grace, charity, and justice (Kreisel, 2012). That is, at one of the critical points in Maimonides's thought, he teaches that the ultimate goal is that the individual, even the excellent individual, will serve the collective, just as God is described in Scripture as lending his goodness to the world. 
Unlike Maimonides, Spinoza does not see the prophets as people who have reached human perfection. In his opinion, the prophets have a perfection of the imagination (Ravven, 2001; Pugliese, 2017; Green, 2019), but not intellectual perfection, which is the true human perfection.

Spinoza holds a negative view of the prophets' involvement with political power (Rosenthal, 1997). In the eighteenth chapter of the Theologico-Political Treatise, he claims that the warnings and rebukes of the prophets in the Bible (Grafton, 2020; Krop \& Arab, 2021) did more harm than good. Spinoza even claims that the unbridled moral preaching of the prophets led to civil war. In his opinion, involvement in political rule by religious leaders, even the prophets, is a terrible danger. Not only did Spinoza emphasize the destructive influence of the prophets in biblical literature, in his view, the establishment of a monarchy with a single leader was the cause of many brutal civil wars. Spinoza emphasizes that when the leadership was under the control of the people, there was only a small civil war, in which the victors acted with grace and mercy towards the defeated. Spinoza's goal is to emphasize that a good political society is led by the people, who often strive for peace and freedom, and not by the political intervention of prophets or by a single leader in pursuit of power and glory.

This difference is another expression of the issue of hierarchy that differentiates between MFL and SAL. In this case, MFL is expressed in the fact that Maimonides sees the prophet as the desired leader for the teaching of the true laws originating in God, which are transmitted through the leader to the followers. In contrast, SAL rejects the hierarchical leadership according to which the leader-in this case, the prophet-is the ultimate mediator between the supreme law and the followers.

\section{Conclusion}

Maimonides's mode of leadership, MFL, is a hierarchical form of leadership well adapted to different and changing circumstances, different audiences, and different people. By contrast, the leadership style learned from Spinoza's writings, SAL, is based on non-hierarchical leadership that forgoes obedience and encourages enjoyable encounters.

The difference between the two leadership styles is related to differences in the thinkers' worldviews. Maimonides has a hierarchical worldview, with God at the top of the hierarchy. Accordingly, it is appropriate that his understanding of human reality be constructed similarly to those structures. A hierarchical worldview requires discipline for the heteronomous source out of commitment and not necessarily out of enjoyment.

Unlike Maimonides, Spinoza holds a non-hierarchical worldview of reality, according to which there is no difference between God and nature. Similarly, in his vision of human society, there is no dichotomy between leader and follower; the distinction between the individual and the collective is less stark, and these two entities act in reciprocity. The practical implications are that the desired activity 
is out of enjoyment and not out of commitment (Soyarslan, 2020) or obedience to hierarchical authority.

These two leadership styles share the basic recognition that the individual is part of society and shaped by it and should, therefore, give of himself and his abilities to society. MFL emphasizes commitment to proper action, while SAL emphasizes the inner motivation of enjoyment, which leads to proper action.

Maimonides saw the prophet as the human ideal and best suited to head a state-that is, his religious ideal is expressed in his political-leadership ideal.

Unlike Maimonides, Spinoza neither saw the prophet as having achieved the highest intellectual achievements, nor as to the ideal leader of political society. He rejected the attempt to reconcile the religious ideal with the ideal of leadership, which, according to that reconciliation, embodies the will of God. In Spinoza's view, leadership is not a heavenly matter but a human procedure.

Maimonides's flexibility is reflected in the fact that through the foundations of faith it is possible to bring even simple people closer to adopt philosophical truths, while Spinoza's affective, dynamic, and skeptical approach to the foundations of faith is reflected in the creation of a social infrastructure that prioritizes collaboration and enjoyment. According to MFL, the desired relationship between the individual and the collective is a social expression of obedience to the hierarchical structure of reality. According to SAL, the individual and the collective are empowered by each other in enjoyment relationships and not out of obedience resulting from a hierarchical social structure. Familiarity with both models of leadership can allow for the adaptation of a leadership model to the style of a specific project.

In summary, this study compares the worldviews of Maimonides and Spinoza and the style of leadership learned from those worldviews. The difference between them begins with a different conception of God, includes a different conception of the function of the prophet and prophecy, and continues to the issue of proper society and the human ideal. These differences form the basis for the divergence between the two leaders' perceptions of leadership. Future use of this research may provide a basis to match an audience, with its unique conceptual or operational structure, to the appropriate leadership for that audience. The limitation of this article is that it is theoretical; however, it is an opening for empirical studies on adapting the leadership style to specific organizations.

\section{Conflicts of Interest}

The author declares no conflicts of interest regarding the publication of this paper.

\section{References}

Arbib, D. (2021). Spinoza and Scripture. In Y. Y. Melamed (Ed.), A Companion to Spinoza (pp. 449-461). Wiley Blackwell. https://doi.org/10.1002/9781119538349.ch42

Baron, L., Rouleau, V., Grégoire, S., \& Baron, C. (2018). Mindfulness and Leadership Flexibility. The Journal of Management Development, 37, 165-177. 
Dahlbeck, J. (2021). Spinoza on the Teaching of Doctrines: Towards a Positive Account of Indoctrination. Theory and Research in Education, 19, 78-99. https://doi.org/10.1177/1477878521996235

Dascalu, R. (2017). Imago and Imitatio: Perfection of the Individual and Society in Maimonides' Theory of Religious Law. In N. Doe, P. Babie, \& V. I. Savić (Eds.), Law, Religion and Love (pp. 266-288). Routledge. https://doi.org/10.4324/9781315543734-14

Davies, D. (2011). Method and Metaphysics in Maimonides' Guide for the Perplexed. Oxford University Press. https://doi.org/10.1093/acprof:oso/9780199768738.001.0001

Eisenberg, P. D. (2019). “Is Spinoza an Ethical Naturalist? 1." In S. Hessing (Ed.), Speculum Spinozanum, 1677-1977 (pp. 145-164). Routledge.

https://doi.org/10.4324/9780429317958-8

Fagenblat, M. (2020). 4. Ethical Negative Theology. In M. Fagenblat (Ed.), A Covenant of Creatures (pp. 111-139). Stanford University Press. https://doi.org/10.1515/9780804774680-006

Gandolfi, F., \& Stone, S. (2018). Leadership, Leadership Styles, and Servant Leadership. Journal of Management Research, 18, 261-269.

Gatens, M., Steinberg, J., Armstrong, A., James, S., \& Saar, M. (2021). Spinoza: Thoughts on Hope in Our Political Present. Contemporary Political Theory, 20, 200-231. https://doi.org/10.1057/s41296-020-00406-4

Gilead, A. (2021). Why Spinoza Was Not a Panentheist. Philosophia, 49, 2041-2051. https://doi.org/10.1007/s11406-021-00378-8

Grafton, A. (2020). Baruch Spinoza Reads the Bible. In A. Grafton (Ed.), Inky Fingers (pp. 232-253). Harvard University Press. https://doi.org/10.4159/9780674245679-010

Green, K. (2019). Spinoza and the "Outsider" Prophet. Textual Practice, 33, 859-877. https://doi.org/10.1080/0950236X.2019.1581689

Grossman, E. (2020). Spinoza's Critique of Maimonides in the Context of Dutch Hebraism. Jewish Studies Quarterly, 27, 36-57. https://doi.org/10.1628/jsq-2020-0004

Halbertal, M. (2013). Maimonides: Life and Thought. Princeton University Press.

Halkin, A. S., \& Hartman, D. (1993). Epistles of Maimonides: Crisis and Leadership. Jewish Publication Society.

Hancock, C. (2021). In Search of the Good Life: Through the Eyes of Aristotle, Maimonides, and Aquinas. International Philosophical Quarterly, 61, 123-126.

https://doi.org/10.5840/ipq2021611169

Heemsbergen, B. (2006). The Leader's Brain. Trafford Publishing.

Hoch, L., \& Bentolila, D. (2021). Maimonides: Flexible Leadership. Open Journal of Leadership, 10, 27-38. https://doi.org/10.4236/oj1.2021.101002

Hurtado, P. S., \& Mukherji, A. (2015). Developing a Construct of the Leader's Cognitive Flexibility: An Interdisciplinary Approach. Journal of Competitiveness Studies, 23, 3-12.

Idel, M. (2008). Leadership and Charisma: Maimonides, Nahmanides and Abraham Abulafia. Journal for the Study of Sephardic and Mizrahi Jewry, 1, 2-34.

Jia, X., Chen, J., Mei, L., \& Wu, Q. (2018). How Leadership Matters in Organizational Innovation: A Perspective of Openness. Management Decision, 56, 6-25. https://doi.org/10.1108/MD-04-2017-0415

Jones, S., \& Nieto, C. A. (2015). Developing People for Strategic Leadership. Effective EXecutive, $18,19-24$.

Kaiser, R. B., \& Overfield, D. V. (2010). Assessing Flexible Leadership as a Mastery of Opposites. Consulting Psychology Journal: Practice and Research, 62, 105-118. 
https://doi.org/10.1037/a0019987

Klein, J. R. (2019). Materializing Spinoza's Account of Human Freedom. In N. NaamanZauderer (Ed.), Freedom, Action, and Motivation in Spinoza's Ethics (pp. 152-173). Routledge. https://doi.org/10.4324/9780429350962-8

Kreisel, H. (2012). Maimonides' Political Thought: Studies in Ethics, Law, and the Human Ideal. SUNY Press.

Kreisel, H. (2018). 1. Maimonides' God: The God of Abraham or the God of Aristotle? In H. Kreisel (Ed.), Judaism as Philosophy (pp. 3-18). Academic Studies Press. https://doi.org/10.1515/9781618117892-002

Krop, H., \& Arab, P. T. (2021). Spinoza's Theological-Political Treatise (1670-2020). Commemorating a Long-Forgotten Masterpiece. Philosophies, 6, Article No. 67. https://doi.org/10.3390/philosophies6030067

Landin, J. (2017). Keys to Flexible Leadership. Strategic Finance, 99, 23-24.

LeBuffe, M. (2018). Spinoza on Reason. Oxford University Press. https://doi.org/10.1093/oso/9780190845803.001.0001

Lemler, D. (2018). The Sceptical Exegesis of Maimonides and His Followers. In R. Haliva (Ed.), Scepticism and Anti-Scepticism in Medieval Jewish Philosophy and Thought (pp. 107-129). De Gruyter. https://doi.org/10.1515/9783110553321-007

Lloyd, G. (2018). Spinoza and the Meaning of Life. In S. Leach, \& J. Tartaglia (Eds.), The Meaning of Life and the Great Philosophers (pp. 135-141). Routledge. https://doi.org/10.4324/9781315385945-18

Mahmoodi, M. (2018). Maimonides and His Approach to Anthropomorphic Verses of the Bible. Essays in Philosophy and Kalam, 50, 91-108.

Maimonides, M. (1983). The Book of Knowledge: From the Mishneh Torah of Maimonides. KTAV Publishing House, Inc.

Maimonides, M. (1910). The Guide for the Perplexed. London: Routledge.

Maimonides, M. (1912). Eight Chapters of Maimonides on Ethics. Columbia University Press.

Mander, W. (2012). Pantheism. In E. Zalta (Ed.), Stanford Encyclopedia of Philosophy. Stanford University.

Melamed, Y. (2018). Cohen, Spinoza, and the Nature of Pantheism. Jewish Studies Quarterly, 25, 171-180. https://doi.org/10.1628/jsq-2018-0007

Munro, I., \& Thanem, T. (2018). The Ethics of Affective Leadership: Organizing Good Encounters without Leaders. Business Ethics Quarterly, 28, 51-69.

Munro, I., \& Thanem, T. (2020). Care without Leaders: The Collective Powers of Affective Leadership. In L. Tomkins (Ed.), Paradox and Power in Caring Leadership (199-210). Edward Elgar Publishing. https://doi.org/10.4337/9781788975506.00028

Naaman-Zauderer, N. (2019). Spinoza on Human Freedoms and the Eternity of the Mind. In N. Naaman-Zauderer (Ed.), Freedom, Action, and Motivation in Spinoza's Ethics (pp. 198-221). Routledge. https://doi.org/10.4324/9780429350962-10

Newlands, S. (2010). The Harmony of Spinoza and Leibniz. Philosophy and Phenomenological Research, 81, 64-104. https://doi.org/10.1111/j.1933-1592.2010.00354.x

Novicevic, M. M., Williams, L. A., Abraham, D. R., Gibson, M. C., Smothers, J., \& Crawford, A. L. (2011). Principles of Outstanding Leadership: Dale Carnegie's Folk Epistemology. Journal of Applied Management and Entrepreneurship, 16, 4-22.

Pillay, S. S. (2010). Your Brain and Business: The Neuroscience of Great Leaders. Pearson FT Press.

Popejoy, M. (2019). Pantheism in Spinoza, Hegel, and Contemporary Philosophy of Reli- 
gion. Doctoral Dissertation, Purdue University Graduate School.

Přibáň, J. (2018). Constitutional Imaginaries and Legitimation: On Potentia, Potestas, and Auctoritas in Societal Constitutionalism. Journal of Law and Society, 45, S30-S51. https://doi.org/10.1111/jols.12118

Pugliese, N. (2017). Spinoza's Argument for a Bodily Imagination. Filosofia Unisinos, 18, 172-176. https://doi.org/10.4013/fsu.2017.183.07

Ravven, H. M. (2001). Some Thoughts on What Spinoza Learned from Maimonides about the Prophetic Imagination: Part 1. Maimonides on Prophecy and the Imagination. Journal of the History of Philosophy, 39, 193-214.

https://doi.org/10.1353/hph.2003.0110

Carrasquillo, F. J. R. (2019). Philosophy and the Metaphorical Interpretation of Religious Texts in Averroes, Maimonides, and Aquinas. The Muslim World, 109, 627-647.

Rosenthal, M. (1997). Why Spinoza Chose the Hebrews: The Exemplary Function of Prophecy in the Theological-Political Treatise. History of Political Thought, 18, 207-241.

Shapira, H. (2018). The Virtue of Mercy according to Maimonides: Ethics, Law, and Theology. Harvard Theological Review, 111, 559.

Shemesh, A. O. (2018). The Physician vs. the Halakhic Man: Theory and Practice in Maimonides's Attitude towards Treating Gentiles. Journal for the Study of Religions and Ideologies, 17, 18-31.

Soyarslan, S. (2020). From Humility to Envy: Questioning the Usefulness of Sad Passions as a Means towards Virtue in Spinoza's Ethics. European Journal of Philosophy, 28, 3347.

Spinoza, B. (2003). Ethics. Ha Kibbutz Ha Meuhad.

Spinoza, B. (2013). The Political Treatise. The Hebrew University.

Tucker, E. (2019). Spinoza, Religion, and Recognition. In M. Kahlos, H. J. Koskinen, \& R. Palmén (Eds.), Recognition and Religion (pp. 219-231). Routledge. https://doi.org/10.4324/9780429026089-13

Vasilescu, M. (2019). Leadership Styles and Theories in an Effective Management Activity. Annals-Economy Series, 4, 47-52.

Weiler, G. (2018). Politics, Authority and Prophecy in Maimonides. Religious Traditions: A New Journal in the Study of Religion/Journal of Studies in the Bhagavadgita, 3.

Whitman, N. L. (2020). Out of Many: Prophecy and Sovereign Authority in Maimonides' and Spinoza's Politics. In An Examination of the Singular in Maimonides and Spinoza (pp. 47-108). Palgrave Macmillan. https://doi.org/10.1007/978-3-030-49472-8 3

Whitman, N. L. (2020). Prophecy and Intuition: Singular Knowledge in Maimonides' and Spinoza's Philosophy. In An Examination of the Singular in Maimonides and Spinoza (pp. 11-46). Palgrave Macmillan. https://doi.org/10.1007/978-3-030-49472-8 2

Wilkes, J., Yip, G., \& Simmons, K. (2011). Performance Leadership: Managing for Flexibility. The Journal of Business Strategy, 32, 22-34.

Youpa, A. (2019). The Empowered Life: Freedom. In A. Youpa (Ed.), The Ethics of Joy: Spinoza on the Empowered Life (pp. 126-142). Oxford University Press. https://doi.org/10.1093/oso/9780190086022.003.0009

Yovel, Y. (1989). Spinoza and Other Heretics. Princeton University Press.

Yukl, G., \& Mahsud, R. (2010). Why Flexible and Adaptive Leadership Is Essential. Consulting Psychology Journal: Practice and Research, 62, 81.

Yukl, G. (2008). The Importance of Flexible Leadership. In R. B. Kaiser (Ed.), the 23rd Annual Conference of the Society for Industrial-Organizational Psychology (pp. 2-7). 